\title{
Characterization of Samples from the Effluent Treatment Facility Evaporator Waste Concentrate Tank
}

by

W. R. Wilmarth

Westinghouse Savannah River Company

Savannah River Site

Aiken, South Carolina 29808

This paper was prepared in connection with work done under the above contract number with the U.S. Department of Energy. By acceptance of this paper, the publisher and/or recipient acknowledges the U.S. Government's right to retain a nonexclusive, royalty-free license in and to any copyright covering this paper, along with the right to reproduce and to authorize others to reproduce all or part of the copyrighted paper. 

Concentrate Tank (U)

W. R. Wilmarth

Publication Date: January 31, 1998

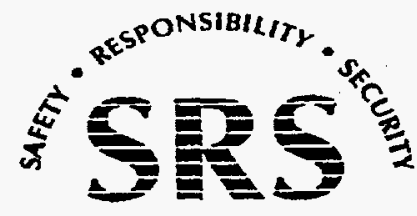




\section{DISCLAIMER}

This report was prepared as an account of work sponsored by an agency of the United States Government. Neither the United States Government nor any agency thereof, nor any of their employees, makes any warranty, express or implied, or assumes any legal liability or responsibility for the accuracy, completeness, or usefulness of any information, apparatus, product, or process disclosed, or represents that its use would not infringe privately owned rights. Reference herein to any specific commercial product, process, or service by trade name, trademark, manufacturer, or otherwise does not necessarily constitute or imply its endorsement, recommendation, or favoring by the United States Government or any agency thereof. The views and opinions of authors expressed herein do not necessarily state or reflect those of the United States Government or any agency thereof.

This report has been reproduced directly from the best available copy.

Available to DOE and DOE contractors from the Office of Scientific and Technical Information, P.O. Box 62, Oak Ridge, TN 37831; prices available from (615) 576-8401.

Available to the public from the National Technical Information Service, U.S. Department of Commerce, 5285 Port Royal Road, Springfield, VA 22161. 


\section{DISCLAIMER}

Portions of this document may be illegible electronic image products. Images are produced from the best available original document. 


\title{
Characterization of Samples from the Effluent Treatment Facility Evaporator Waste Concentrate Tank (U)
}

\author{
W. R. Wilmarth \\ Waste Processing Technology Section \\ Savannah River Technology Center \\ Westinghouse Savannah River Company
}

\section{$\underline{\text { Summary }}$}

During October 1997, the ETF Evaporator Waste Concentrate Tank No.2 was discovered to contain a significant accumulation of solid deposits. SRTC performed destructive and nondestructive examination of solid samples from the tank. The results of these tests indicate that the solids contain mixtures of sodium oxalate (65\%), the sulfide enclathrated sodium aluminosilicate (30\%), and iron oxide $(5 \%)$.

\section{Introduction}

The Effluent Treatment Facility (ETF) collects, treats, and discharges radioactive wastewater from various High Level Waste and Nuclear Material Storage and Stabilization facilities at the Savannah River Site. The ETF treatment involves a series of processes which include $\mathrm{pH}$ adjustment, sub-micron filtration, ion exchange and evaporation. Decontaminated liquids are determined to meet the regulatory requirements proceed to discharge at a permitted outfall. Concentrated liquids containing the majority of the radionuclide components transfer to Saltstone for final disposal in grout.

During a recent liquid transfer from the ETF Waste Concentrate Tank No. 2 to Saltstone, a discrepancy in the total volume of liquid occurred. The Waste Concentrate Tank has a capacity of 1850 gallons and is 84 inches tall. Once the tank reaches capacity, operators $\mathrm{pH}$ adjust the liquid. Inspection of the Waste Concentrate Tank No. 2 by the High Level Waste Surveillance, Monitoring and Remote Technology group revealed significant solid deposits. The Savannah River Technology Center was requested ${ }^{1}$ to analyze a sample of these solids to determine the chemical constituents.

\section{Experimental}

Approximately 52.4 grams (ETF-001) were collected from the tank and transferred to SRTC for chemical analysis. The sample consisted of a dozen or more large pieces. The pieces appeared reddish in color and were moist. Personnel removed representative samples and submitted for 
Scanning Electron Microscopy ${ }^{2}$ and X-ray Diffraction analysis. ${ }^{3}$ Following a sodium peroxide fusion dissolution, ${ }^{4}$ personnel analyzed the liquid for soluble metals by Inductively Coupled Plasma - Emission Spectroscopy. ${ }^{5}$

Laboratory notebook WSRC-NB-97-62 contains data obtained during these tests and the procedures used. Personnel used routine analytical protocol for the samples in this report. ${ }^{6}$

\section{Experimental Results}

Figure 1 shows the X-ray Diffraction spectrum obtained for a ground sample of the solids from the ETF Waste Concentrate Tank No. 2. The spectral peaks correlate with those spectral peaks from reference spectra of sodium oxalate $\left(\mathrm{Na}_{2} \mathrm{C}_{2} \mathrm{O}_{4}\right)$, sodium aluminosilicate sulfide $\left(\mathrm{Na}_{8} \mathrm{Al}_{6} \mathrm{Si}_{6} \mathrm{O}_{24} \mathrm{~S} \bullet 4 \mathrm{H}_{2} \mathrm{O}\right)$ and hermatite (iron oxide, $\left.\mathrm{Fe}_{2} \mathrm{O}_{3}\right)$. Comparison of these reference spectra with the spectrum of the sample shows excellent agreement in both intensity and diffraction . angle, 2 $\theta$. All observed diffraction peaks correlate to the reference spectra. The sodium aluminosilicate observed in the EFT Waste Concentrate Tank No. 2 comes from the same chemical family as the material recently discovered in the $242-16 \mathrm{H}$ Evaporator Gravity Drain Line. $^{7}$

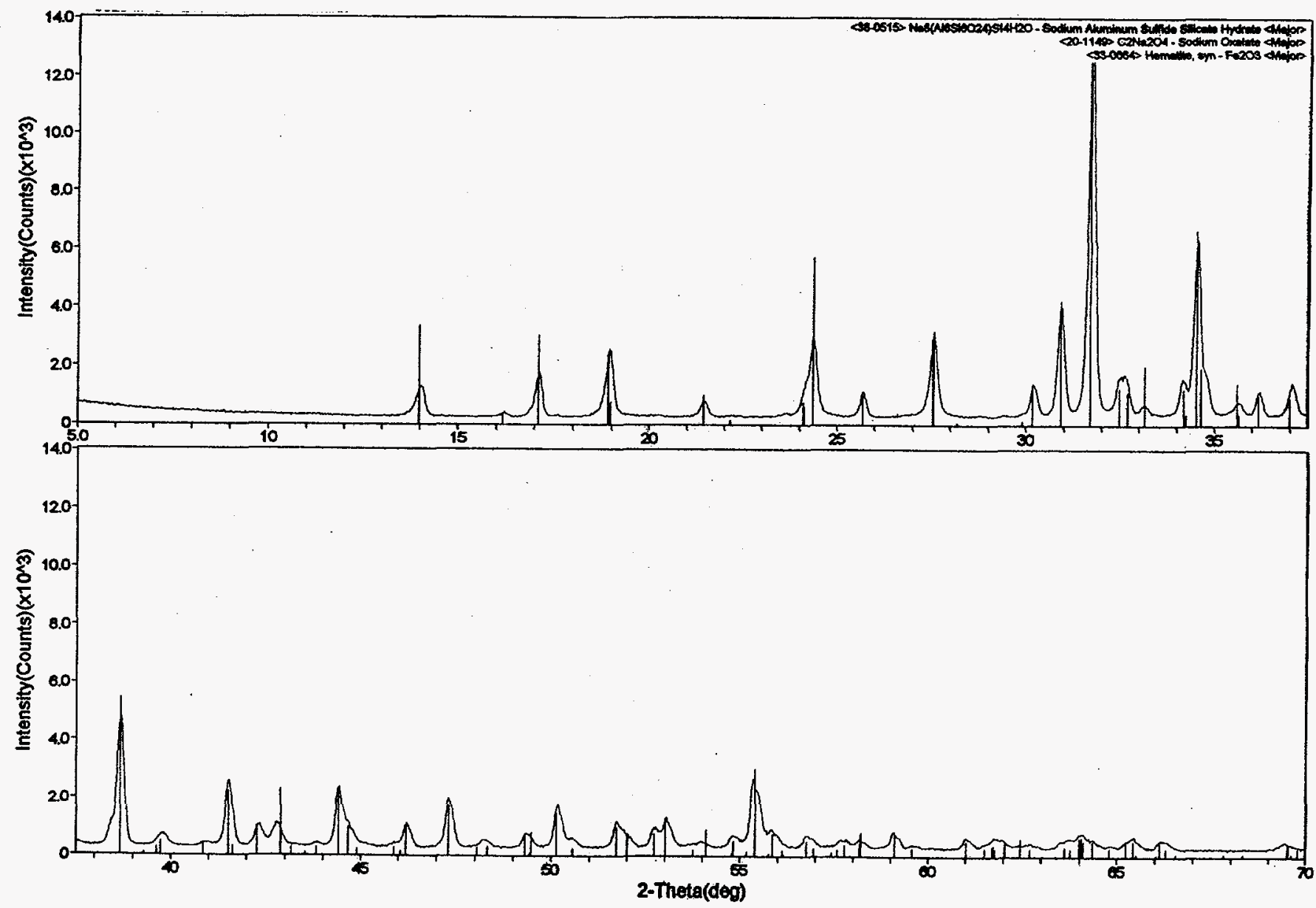

Figure 1. X-ray Diffraction Spectrum of ETF Waste Concentrate Solids 
Although the reference spectrum for the sulfide enclathrated sodium aluminosilicate best matched the sample spectrum, the presence of this compound appears unlikely given the lack of sulfide in the ETF process. The peak pattern observed in the X-ray spectra primarily reflects the structure of the aluminosilicate anion. Only slight spectral differences exist between the sulfide, hydroxy, or nitrate compounds. The moisture content of this sample might cause the nitrate or hydroxy spectra to appear more like that of the sulfide.

Figures 2, 3, and 4 show the Scanning Electron Microscopy (SEM) spectra obtained from different regions of the sample (ETF-001). In Figure 2, a single major peak exists for sodium with minor peaks for aluminum, silicon, iron, and nickel. This spectrum resembles that of sodium oxalate $\left(\mathrm{Na}_{2} \mathrm{C}_{2} \mathrm{O}_{4}\right)$ with very low scattering cross sections for the carbon and oxygen atoms. The contained Scanning Electron Microscopy unit is unable to detect these low atomic weight elements.

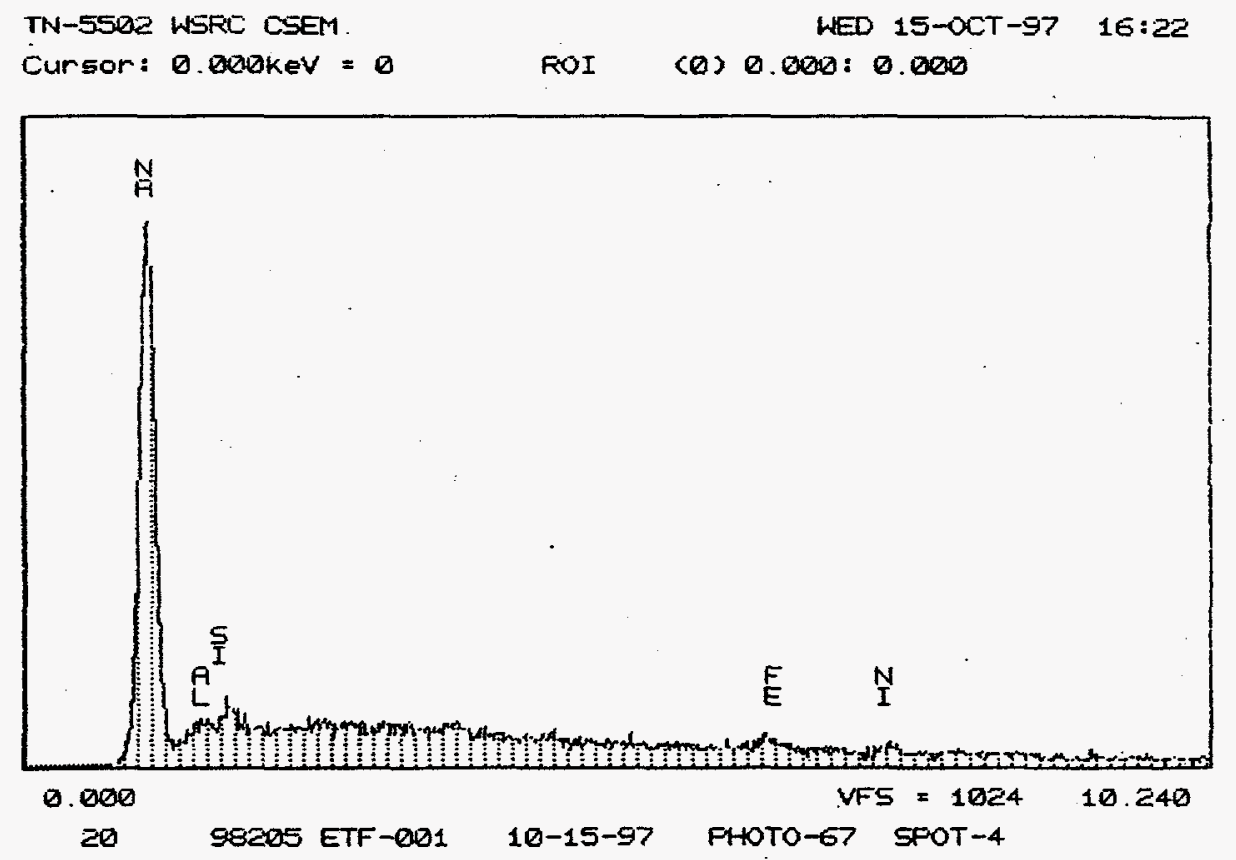

Figure 2. SEM Spectrum of Oxalate-Rich Portion of ETF Solids 
Similarly, Figure 3 shows an SEM spectrum very rich in iron indicative of the iron oxide located in the X-ray Diffraction spectrum and consistent with the samples reddish color. Figure 4 shows the SEM spectrum of a portion of the ETF Waste Concentrate sample that is consistent with the sodium aluminosilicate previously found in the H-Area Gravity Drain Line. Minor peaks of other elements occur in each of the spectra corresponding to calcium and nickel. Additional spectra show mixtures of all of the above mentioned materials and stainless steel.
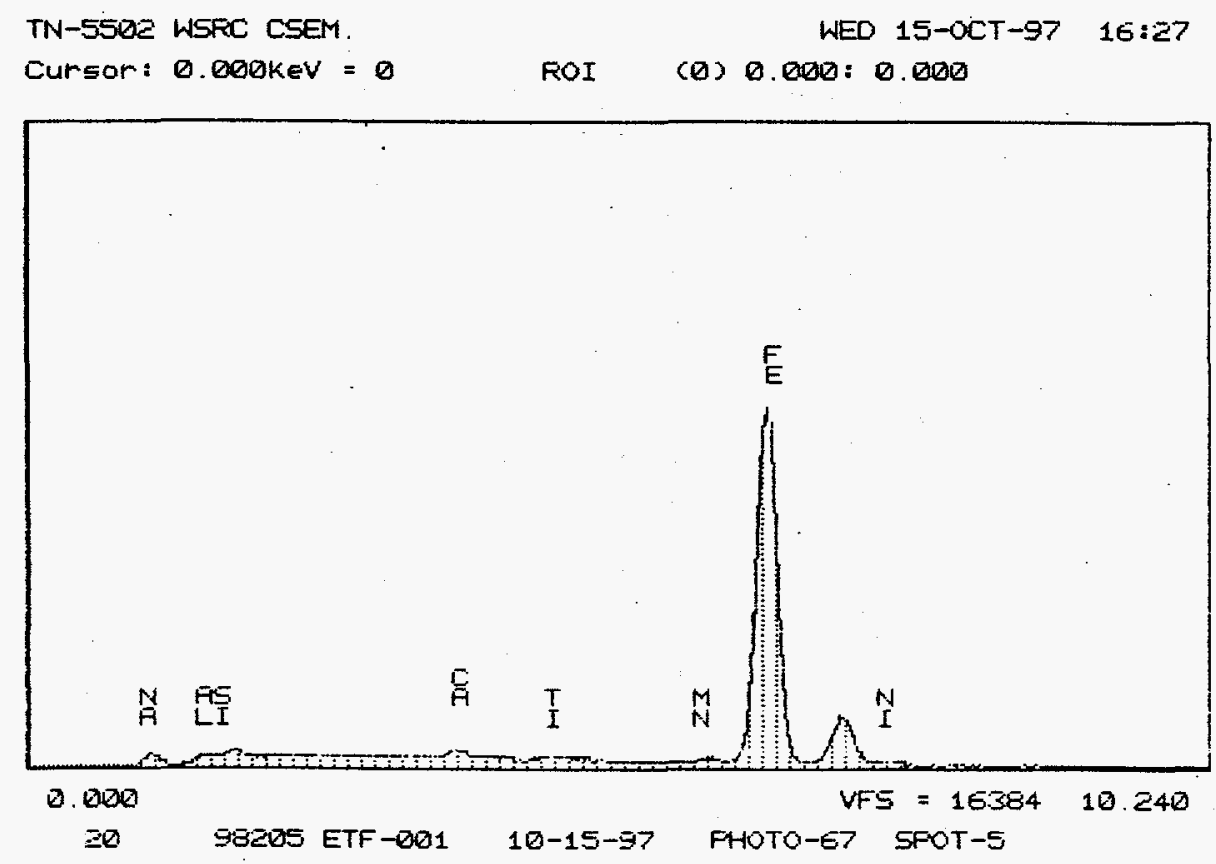

Figure 3. SEM Spectrum of Iron Oxide-Rich Portion of ETF Solids 


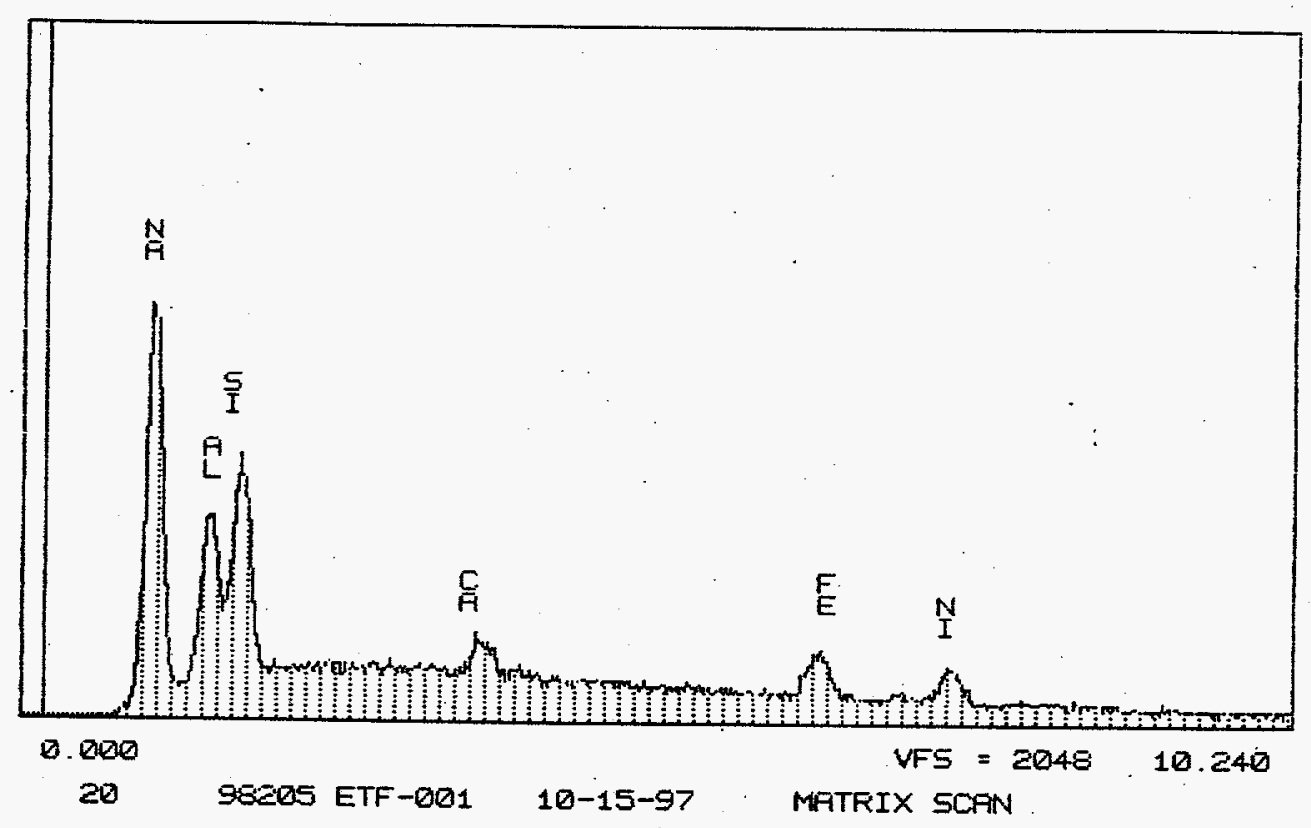

Figure 4. SEM Spectrum of Sodium Aluminosilicate-Rich Portion of the ETF Solids

Personnel performed a sodium peroxide fusion dissolution on a representative portion of solids. This technique involves heating the sample with a quantity of sodium peroxide followed by dissolution in nitric acid. Liquid samples were submitted for analysis by Inductively Coupled Plasma - Emission Spectroscopy (ICP-ES). Table 1 lists the results of these analyses.

Analysis of the ICP-ES data reveals good agreement with the non-destructive analyses. Aluminum and silicon exist in equal molar quantities suggesting agreement with the sodium aluminosilicate molecular formula, i.e., 1:1. Iron is detected in the sample at a percentage roughly in relation to the ratio of aluminosilicate to iron oxide (i.e., $\mathrm{Si}: \mathrm{Fe}=1: 1$ ) observed in the $\mathrm{X}$-ray Diffraction analyses. Magnesium, molybdenum and zinc are the only other constituents 
observed in the ICP-ES scan. Sodium, normally detected in the routine ICP-ES scan, is blinded by the sodium peroxide used in the dissolution technique.

Table 1. ICP-ES Data from ETF Waste Concentrate Tank No.2 Solids

\begin{tabular}{lc}
\hline Element & Concentration $(\mathrm{Wt} \%)$ \\
$\mathrm{Al}$ & 4.16 \\
$\mathrm{~B}$ & $<0.013$ \\
$\mathrm{Ba}$ & $<0.0056$ \\
$\mathrm{Ca}$ & 0.323 \\
$\mathrm{Cd}$ & $<0.003$ \\
$\mathrm{Co}$ & $<0.008$ \\
$\mathrm{Cr}$ & $<0.009$ \\
$\mathrm{Cu}$ & $<0.012$ \\
$\mathrm{Fe}$ & 0.6082 \\
$\mathrm{La}$ & $<0.023$ \\
$\mathrm{Li}$ & $<0.008$ \\
$\mathrm{Mg}$ & 0.0461 \\
$\mathrm{Mn}$ & 0.018 \\
$\mathrm{Mo}$ & $<0.010$ \\
$\mathrm{Ni}$ & $<0.017$ \\
$\mathrm{P}$ & $<0.027$ \\
$\mathrm{~Pb}$ & $<0.045$ \\
$\mathrm{Si}$ & 4.419 \\
$\mathrm{Sn}$ & $<0.014$ \\
$\mathrm{Sr}$ & $<0.003$ \\
$\mathrm{Ti}$ & $<0.009$ \\
$\mathrm{~V}$ & $<0.012$ \\
$\mathrm{Zn}$ & 0.006 \\
\end{tabular}

\section{Conclusions}

Samples of solid deposits from the Effluent Treatment Facility Waste Concentrate Tank No. 2 were obtained and delivered to SRTC after a visual inspection showed significant accumulation. Portions of this sample were analyzed by destructive and non-destructive methods to determine the chemical constituents of the solid. Results of these analyses indicate a chemical composition consisted of sodium oxalate (65\%), the sulfide enclathrated sodium aluminosilicate $(30 \%)$, and iron oxide (5\%). The recommended method of cleaning would dissolve the sodium oxalate component of the solid deposits in hot water. The insoluble iron oxide and sodium aluminosilicate components could then be filtered. 


\section{References}

1. A. W. Wiggins, “Analyze ETF Waste Concentrate Tank Sample," HLE-TAR-97009, October 29, 1997.

2. "Procedure for Contained Scanning Electron Microscopy (CSEM) (U)," Manual L16.1, Procedure ADS-1100, Rev. 5, August 31, 1997.

3. "Siemens D-500 Contained X-Ray Diffraction System (U)," Manual L16.1, Procedure ADS1101, Rev 3, December 15, 1995.

4. "Sodium Peroxide/Sodium Hydroxide Dissolution of Sludge and Glass for Elemental and Anion Analysis," Manual L16.1, Rev. 3, February 2, 1996.

5. "Inductive Coupled Plasma - Emission Spectrometer for Aqueous Liquid Sample Analysis," Manual L16.1, Procedure ADS-1509, June 25, 1996.

6. “Obtaining Analytical Services, “Manual L1, Procedure 3.07, Rev. 0, August 6, 1993.

7. W. R. Wilmarth, S. D. Fink, D. T. Hobbs and M. S. Hay, "Characterization and Dissolution Studies of Samples from the 242-16H Evaporator Gravity Drain Line (U)," WSRC-RP-970326, Rev. 0, October 16, 1997. 
W. R. Wilmarth

Approval:

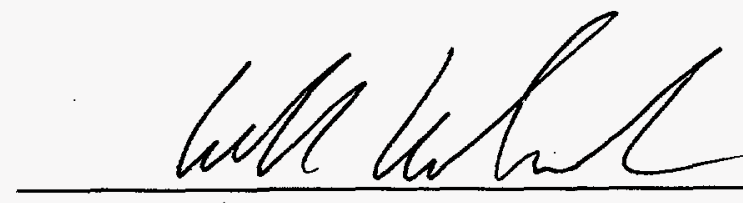

W. R. Wilmarth, Waste Processing Technology

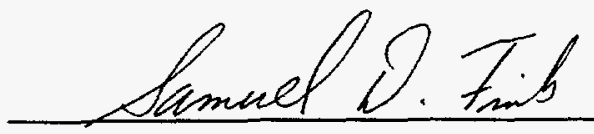

S. D. Fink, Manager Liquid Waste Processing
WSRC-RP-98-00034

Page 10 of 10

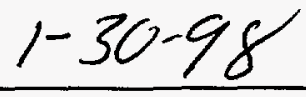

Date

Date

A.w. ace

$2 / 5 / 98$

Date

A. W. Wiggins, Manager SW\&ER Division Engineering 


\section{DISTRIBUTION}

Barnes, J. L., 704-S

Barnes, M. J., 773-A

Bragg, T. K., 241-197H

Brooke, J. N., 773-A

Britt, T. E., 703-H

Carter, J. T., 704-56H

Cauthen, G. L., 241-119H

Clark, W. C., 704-56H

Crawford, C. L., 773-41A

Doughty, D. E., 704-56H

Eibling, R. E., 704-T

Elder, H. H., 704-S

Fink, S. D., 773-A

Fowler, J. R., 704-Z

Fowler, R. C., 241-152H

Hay, M. S., 773-A

Herrara, H. F., 703-H

Hester, J. R. 703-H

Hitchler, M. J., 992-3W

Hobbs, D. T., 773-A

Holtzscheiter, E. W., 773-A

Hsu, C. W., 773-A

ITP Files c/o Wiest, A. G., 241-119H

Kirkland, Penny, 703-46A,

Jacobs, R. A., 704-T

Jamison, M.E., 703-H

Johnson, M. D., 703-H

Keefer, M. T., 704-56H

Landon, L. F., 704-T

Lewis, B. L., 703-H

Lex, T. J., 703-H

Lowe, P. E., 773-42A

Marek, J. C., 704-T

McCabe, D. J., 773-43A

McCullough, J. W., 703-H

Melton, W. L., 241-154H

Menna, J. D., 992-3W

Miller, M. S., 704-56H

Montini, M. J., 704-56H

Morin, J. P., 703-H

Nash, C. A., 773-42A

Nelson, L. M., 773-43A

Norkus, J. K., 992-3W

Papouchado, L. M., 773-A

Peterson, R. A., 773-A

Pervis, D. A., 241-152H

Piccolo, S. F., 704-56H

Randall, C. T., 704-T

Rutland, P. L., 704-56H

Satterfield, R. M., 703-H

Scott, A. B., 703-H

Stevens, W. E., 773-A

Suggs, P. C., 703-H

Swingle, R. F., 773-A

Tamosaitis, W. L., 773-A

Taylor, G. A., 703-H

Thomas, J. K., 730-2B

Van Pelt, W. B., 679-T

Walker, D. D., 773-A

Walker, W. C., 241-119H

Wiggins, A. W., 241-84H

Wilmarth, W. R., 773-42A

Wooten, A. L., 992-3W

Wright, G. T., 773-A

WPT-LWG Files, 773-A

TIM (4), 703-43A

RECORD ADMINSTRATION, 773-52A 